\title{
INNOVATIVE PERFORMANCE AND INNOVATION SYSTEM OF LATVIA
}

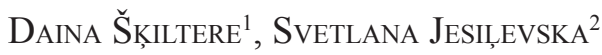 \\ University of Latvia (Latvia)
}

\begin{abstract}
The research and analysis of strengths and weaknesses of national innovation system is extremely important to successful and efficient innovation support policymaking. Innovation support policies should take into consideration all specifies of national innovation system in the country, not being one-size-fits-all. Until now, little analysis on the Latvian innovation system was made. The paper aims to show Latvian innovative performance and to propose factors for well-functioning innovation system of Latvia. This research gives a possibility to researchers and policy-makers to investigate the mismatch between policies and problems and identify policy gaps.

KEY WORDS: innovative performance, innovation system, statistical information.
\end{abstract}

JEL CODES: C10, O31.

\section{Introduction}

Research problem: The innovation systems (IS) concept emphasizes that the technological and information flows between people, enterprises and organizations play a major role to the innovative process. Innovation and technological improvement are the result of a set of relationships between enterprises, universities and government research institutes, which all are the actors of complex system of innovation. The research and analysis of strengths and weaknesses of innovation system is extremely important to successful and efficient innovation support policymaking. Innovation support policies should take into consideration all specifies of innovation system in the country, not being one-size-fits-all. Analysis and understanding of the innovation system can help policy-makers to identify strategies for improving innovative performance and overall competitiveness of the national economy. Policies aiming to improve co-operation between the enterprises and institutions in the innovation system and to increase the innovative capacity of enterprises, in particular their ability to identify and absorb new technologies, are most valuable in this context. Until now, little analysis on the Latvian innovation system was made.

Research purpose is to show Latvian innovative performance and to propose factors for wellfunctioning innovation system of Latvia.

Research object: Latvian innovation system and factors for its well-functioning.

Research methods: bibliography review, as well as methods of statistical analysis such as grouping, processing and comparative analysis has mainly been used in the paper.

Daina Šksiltere - dr. oec., professor, head of the Chair of economic systems management theory and methods, Faculty of Economics and Management, University of Latvia

E-mail: dainask@1u.lv

2 Svetlana Jesiļevska - mg. oec., Faculty of Economics and Management, University of Latvia, Central statistical bureau of Latvia. Scientific interests: innovations, statistics

E-mail: svetlana.jesilevska@csb.gov.lv 
This research gives a possibility to researchers and policy-makers to investigate the mismatch between policies and problems and identify policy gaps.

\section{Defining national innovation system}

The several attempts were made to define the concept of national innovation system. Lundvall (Lundvall, 1992) separates a broad and a narrow definition of the innovation system. The narrow definition includes organizations and institutions involved in research and exploring, such as R\&D departments, technological institutes and universities. In turn, the broad definition is a system of actors and relationships which interact for the production, diffusion and use of new and economically useful knowledge.

One can conclude that the main elements of national innovation systems are institutions and linkages. Johnson (Johnson, 1992) defines 'institutions are set of habits, routines, rules, norms and laws, which regulate the relations between people, and shape social interaction'.

In turn, linkages and flows include human flows between universities, enterprises, and government laboratories, financial flows between government and private organizations, regulation flows from government bodies towards innovative organizations, and knowledge flows among these institutions. Their characteristics may be helpful or harmful to the smart and efficient operation of the national innovation systems (Niosi, 2002).

In Latvia several definitions of national innovation system exists. Enterprise Europe Network Latvia provides the following definition: 'National Innovation System is defined as structure of national economy and environment necessary for productive innovation. Innovation system has four basic components: 1) research (science and education); 2) entrepreneurship; 3) investment (financial system); 4) legislation' (Enterprise Europe Network Latvia). In author's opinion this definition is uncertain as it does not explain how to ensure appropriate structure and environment of national economy for successful innovation activities and does not give any further explanation on the criteria to evaluate the compliance of structure and environment of national economy.

Latvian Program for Promotion of Business Competitiveness and Innovation 2007-2013 defines national innovation system as 'aggregate of governmental, public and private sector institutions and events implemented by them, which promotes creation, storage, exchange and practical application of new knowledge. It includes research (education, science, and creation), business, financial system, legislation.' (Program for Promotion of Business Competitiveness and Innovation 2007-2013). In authors' view, this definition does not take into account that a system is not just a set of the government, the public and private sector institutions, but rather some kind of their interaction.

One more definition, provided by, Watkins \& Agapitova in Creating a 21st Century National Innovation System for a 21 st Century Latvian Economy is 'way of interaction between the private sector, higher education institutions, research institutes and government policy to create inventions and innovations, the results of which can be converted into new products and production processes, which contribute to a competitive advantage of public enterprises' (Watkins \& Agapitova, 2002). This definition mentions only the necessity to achieve a competitive advantage of public enterprises, nothing is said about the consumer needs.

The authors developed the following definition: the innovation system is the system of close co-operation between private and public enterprises, universities, private and public research institutions, government bodies aiming at developing innovation in accordance with consumers' needs for new or developed products or services. The dictionary defines the term 'co-operation' as 'an act or instance of working or acting together for a common purpose or benefit; joint action', in turn 'interaction' is defined as 'a reciprocal action, effect, or influence'. Why co-operation not interaction? The authors believe that the functioning of innovation system should be based on co-operation rather than on interaction as for successful and productive innovation results, the financial, legal etc. decisions in any level of the system of innovations should be made in accordance with needs, strengths and weaknesses of all actors of the system. Only in these circumstances, all the actors will work as a team, as a single innovation system. One more significant issue that should be taken into 
consideration is that the production of novelty would be of little value to enterprises if there were no market for the consumption of novelty in households. That is why recognising the existence, and understanding the nature, of this demand is essential.

\section{The innovation performance}

Latvia has performed badly in terms of R\&D and innovation. According to the last innovation and R\&D survey results, between the EU27 Member States Latvia is one of the countries with the lowest proportion of innovative enterprises. According to the EU rating of innovativeness in 2008-2010, Latvia was the third worst performer after Bulgaria and Poland. Survey data (see Table 1) show that, during the time period from 2008 till 2010, in Latvia $29.9 \%$ of enterprises introduced innovations. The most popular way to innovate in 2008-2010 was through introducing new processes. The percentage of innovators who introduced process innovation is $19.2 \%$. Product innovations are less widespread. Only about $15.2 \%$ of innovators offered new products. The majority of innovations were developed in large enterprises (62.2\%). About $31.7 \%$ of innovation-active enterprises during 2008-2010 were active in Industry and only $28.3 \%$ - in Services spheres.

The results on the last Community Innovation Survey (CIS 2010) show that the highest propensities to innovate were recorded in Estonia (56.8 \% of total enterprise number are innovative enterprises). The share of innovative enterprises in Latvia and Lithuania are lower than in Estonia and are approximately at the same level. According to the CIS 2010 results (see Table 1), Estonian innovation performance is better than Latvian and Lithuanian.

Table 1. Innovation active enterprises as per cent of total enterprise number, 2008-2010

\begin{tabular}{|l|c|c|c|}
\hline & Latvia & Lithuania & Estonia \\
\hline Total & 29.9 & 32.5 & 56.8 \\
\hline of which with number of the employed: & & & \\
\hline $10-49$ & 26.7 & 27.9 & 51.7 \\
\hline $50-249$ & 38.4 & 43.1 & 73.3 \\
\hline$\geq 250$ & 62.2 & 69.6 & 92.5 \\
\hline
\end{tabular}

Source: Research and Development and Innovation Statistics, Statistical Data Collection, 2012, p. 53.

In accordance with Innovation Union Scoreboard 2011 results, Latvia, Lithuania and Estonia fall into different performance groups: Estonia is the 'Innovation follower', but Latvia and Lithuania belong to 'Modest innovators'. Moreover, Estonia is one of the growth leaders with an average annual growth rate well above $5 \%$. Estonian relative strengths are in Human resources, Finance and support, Firm investments, Linkages $\&$ entrepreneurship and Innovators, relative weaknesses are in Open, excellent and attractive research systems, Intellectual assets and Economic effects. Lithuanian relative strengths are in Human resources and Finance and support. Relative weaknesses are in Open, excellent and attractive research systems, Linkages $\&$ entrepreneurship, Intellectual assets, Innovators and Economic effects. According to Innovation Union Scoreboard 2011 results Latvia is one of the modest innovators with a below average performance. Relative strengths are in Human resources, Firm investments, Intellectual assets and Economic effects. Relative weaknesses are in Open, excellent and attractive research systems, Finance and support, Linkages \& entrepreneurship and Innovators. High growth is observed Community trademarks and Community designs. A strong decline is observed for Innovative SMEs collaborating with others and License and patent revenues from abroad. Growth performance in Human resources, Open, excellent and attractive research systems and Intellectual assets is well above average (Innovation Union Scoreboard, 2011).

Although some scientists have made a contribution to developing the Latvian innovation system concept (e.g. Boḷšakovs, 2008; Watkins \& Agapitova, 2002), study on national innovation system concept in Latvia 
as a whole is still at the early stage because of lack of legislation, officially adopted and approved definition and concept of national innovation system.

Why do we need to study the Latvian innovation system, to analyse its strengths and weaknesses and as a result to develop its structure? The innovative performance reflects the preconditions for innovative output provided by the institutional and socio-economic structures of the national innovation system as a whole (Lundvall, 2009). Each country should develop its own national innovation system as each country has its own institutional profile depending on the governance regime for enterprises, the organisation of the university sector, the level and orientation of government-funded research, priority sectors etc. With a richer understanding of national innovation system concept, it may then be possible for policy-makers to develop policy recommendations that help to produce more systemic and effective IS in Latvia.

\section{Factors for well-functioning Latvian innovation system}

Technology and R\&D nowadays are examined in the innovation system context, which usually means the existence of several related institutions and the development and utilization of technology improvements take place through the complex processes. Moreover, the utilization of the research results needs some additional institutions, like technology transfer centre, a bank, a consulting company, an enterprise etc.

Nowadays, innovation as a result of R\&D activities has started to receive more interest than just science and technology. This tendency also assumes that something more (like marketing, commercializing, financing) is needed to transform good science and technology into real innovation in the world.

In the NIS the main elements of interaction are Knowledge, Finance, and People. The main activities are creation, transfer and utilization of knowledge in the market. For this purpose, all of the innovation actors interact with each other and exchange knowledge, financial and human resources.

In authors' view, the core factors necessary for well-functioning Latvian innovation system are the following: organization of financial system, capabilities and co-operation of Latvian IS institutions, informational support, development of human capital, cultural and historical facts, structure of the economy and distribution of enterprises by size-class (see Figure 1).

An organization of financial system includes the following brightest problems in Latvia: the low level of public and private sector investment, all support programs are financed by the EU Structural funds rather than the public funds. Latvia is aware that an effort in R\&D is necessary to ensure a sustainable development of the country, which has badly suffered from the financial crisis (see Figure 2). Latvia increased its R\&D intensity during the 2000-2008 period by an average annual growth rate of $4.1 \%$, passing from $0.44 \%$ in the year 2000 to $0.61 \%$ in 2008 . This increase has been fuelled thanks to an increase in public R\&D investment, which rose at an average annual growth rate of $7.1 \%$ (from $0.26 \%$ to $0.46 \%$ ). On the other hand, private R\&D fell from $0.18 \%$ to $0.15 \%$. However, with the deterioration of the economic situation in the country, the public and private sector investment in R\&D decreased in 2009 (0.46 \%) and again in 2010 (Country Profile - Latvia).

Capabilities and co-operation between NIS institutions is a broad concept, here we can mention quality of relationship between customers and suppliers, degree of competitive or co-operative behaviour among institutions, enterprises' willingness to co-operate with research institutions and universities, closeness of relationship between enterprises and technology policy. Enterprises play a crucial role in the development of innovations, but the process of development and dissemination of technological improvements includes a complex interaction among enterprises, universities, research centres, government bodies and other organizations. According to last innovation survey, in Latvia in 2008-2010 co-operation between government or public research institutes and enterprises is very low $-13.0 \%$, co-operation between universities or other higher education institutions and enterprises $-19.1 \%$, the highest co-operation is with other enterprises within the same enterprise group $-45.8 \%$ (Research and Development and Innovation Statistics). In authors view, the development of a knowledge-based economy assumes more active co-operation in the sphere of education and research between Latvia, Lithuania and Estonia, not only co-operation between Latvia's institutions and enterprises. 


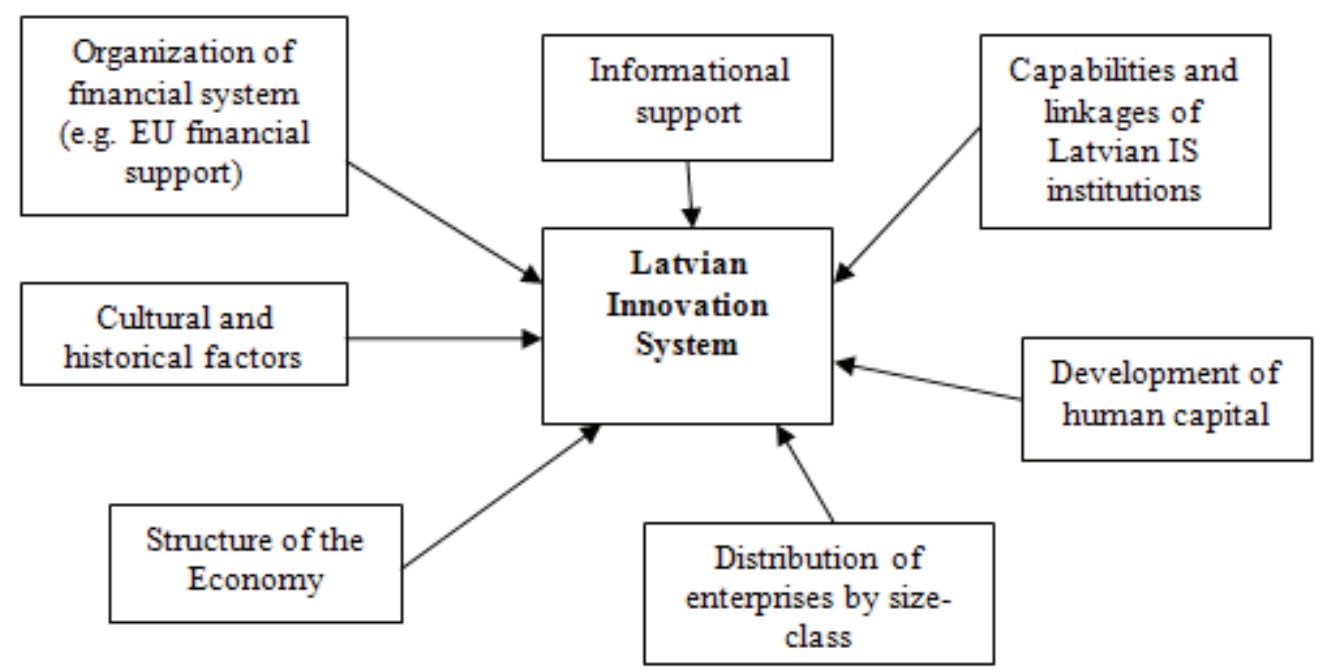

Figure 1. Factors for well-functioning Latvian IS

Source: Authors' construction

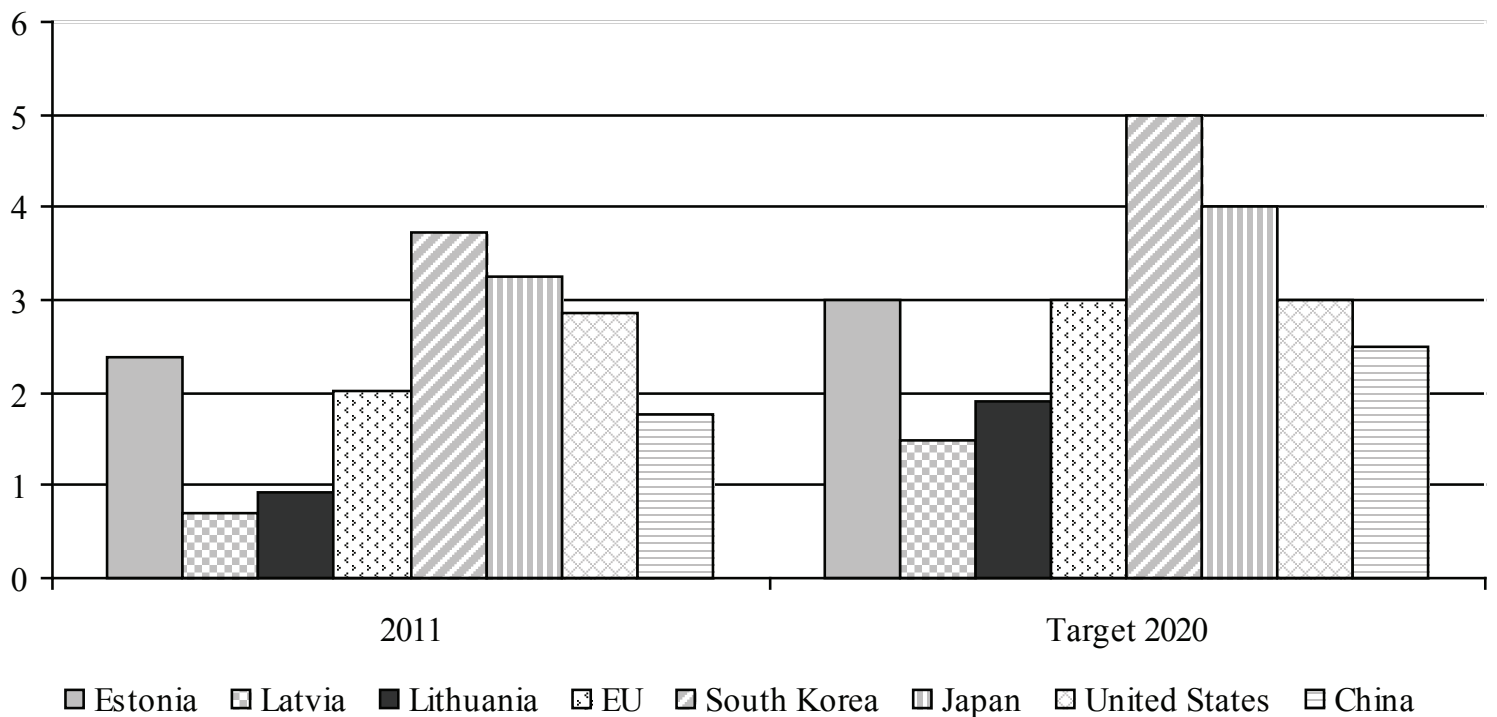

Figure 2. Situation of countries with regard to its R\&D intensity target

Source: Europe 2020 targets: research and development, Eurostat

During Programming Period 2007-2013 only $16 \%$ of EU funding was directed to the Operational Programme 2 'Entrepreneurship and Innovations', which aimed to promote entrepreneurship with higher value added by providing aid in developing and producing new products and technologies, ensuring highlyqualified human resources in enterprises, as well as cooperation of the research and business sectors. About $72 \%$ of EU funding was directed to the Operational Programme 3 'Infrastructure and Services' (Programming Period 2007-2013). Authors argue such an allocation of financial resources as in authors view the development of Latvian national economy cannot be just a 'service-based'. It is impossible to achieve sustainable development or at east economic stability by reducing manufacturing, continuing to import consumption goods from abroad and expanding financial sector to pay for it. The larger proportion of funding should be directed development of science and research to facilitate knowledge-based national economy. The EU funds in Latvia are administered by the Investment and Development Agency of Latvia. 
One more important factor for well-functioning of Latvian IS is informational support, including statistical data. In today's rapidly changing, increasingly interdependent world, productive debate and policy decisions require trustworthy, comparable, and understandable statistical information (Jesilsevska, 2012). The importance of statistics is captured in the following statement: 'Why do statistics matter? In simple terms, they are the evidence on which policies are built. They help to identify needs, set goals and monitor progress. Without good statistics, the development process is blind: policy-makers cannot learn from their mistakes and the public cannot hold them accountable' (World Bank, 2000). Othman (Othman, 2005) show that proper and efficient use of statistics leads to better policy and development outcomes, e.g. good statistics help to inform the design and choice of policy, in forecasting the future, to monitor policy implementation. According to the laws of the Republic of Latvia, Cabinet Regulations and the By-Laws of the Central Statistical Bureau, the CSB is a direct administration body subordinated to the Ministry of Economics and acting as the main performer and coordinator of the official statistical work in the country. That is why authors decided to include in the Latvian innovation system the CSB.

Under the development of human capital we would mention not only development of technical human capital base initially, but also the actions to attract foreign human resources, that would make a decisive contribution to the transfer of technical knowledge and know-how to Latvia, and this would facilitate early acquirement of developed technology. Innovation economics continuously demands new skills and competences, creates the need to repeatedly and regularly improve one's knowledge and skills, to return to school in order to adapt to the changing needs of the labour market. However, educational system of Latvia is not sufficiently flexible in responding to the needs of adult further education. One more aspect here is that the success of Latvian economy depends on the ability and willingness of entrepreneurs to search for and use knowledge produced outside Latvia. This process will require certain skills - to understand the knowledge, be able to use it and to adapt it for creating new knowledge. The investments into this area in Latvia are extremely low and should be supported (Jesil̨evska, 2012b).

By cultural and historical factors we mean national values and attitudes towards risk aversion, innovative spirit, mutual trust, time preference, attitude towards technological progress, historical development of the educational, science and financial system.

Distribution of enterprises by size-class is one more essential factor for well-functioning Latvian innovation system. The micro and small enterprises are not only providers of services or goods for consumers, but they help large enterprises to operate more efficiently as they serve as suppliers for large enterprises and as sellers of the products made by large enterprises. According to Eurostat data (see Table 3), in Latvia the small and medium-sized enterprises (SMEs) constitute $99,8 \%$ of the national economy and they are very important for the creation of gross domestic product and employment. Innovative activities in Latvia are dominated by large companies (see Table 1), whereas the small innovative enterprises should be encouraged by the implementation of special financial support policies (Jesiļevska, 2012a).

Table 2. Enterprise size class analysis of non-financial business economy by country, 2009

\begin{tabular}{|l|c|c|c|c|c|}
\hline & $\begin{array}{c}\text { Total number of } \\
\text { enterprises (thousands) }\end{array}$ & Micro (\%) & Small (\%) & Medium-sized (\%) & Large (\%) \\
\hline EU-27 & 20791190 & 92.2 & 6.5 & 1.1 & 0.2 \\
\hline Latvia & 78280 & 88.3 & 9.6 & 1.8 & 0.2 \\
\hline Lithuania & 113059 & 88.0 & 9.9 & 1.9 & 0.2 \\
\hline Estonia & 50600 & 86.8 & 10.7 & 2.1 & 0.3 \\
\hline
\end{tabular}

Source: Statistics Explained

\section{Conclusions and recommendations}

The authors propose the following definition: the innovation system is the system of close co-operation between private and public enterprises, universities, private and public research institutions, government 
bodies aiming at developing innovation in accordance with consumers' needs for new or developed products or services.

As authors see, the core factors necessary for well-functioning Latvian innovation system are the following: capabilities and co-operation of Latvian IS institutions, organization of financial system, informational support, development of human capital, cultural and historical facts, structure of the economy and distribution of enterprises by size-class.

The Ministry of Education and Science should work on ensuring the international recognition of Latvian science and higher education, and the formation of public understanding of the importance of science for the Latvian sustainable development based on science and technology.

An organization of financial system includes the following brightest problems in Latvia: the low level of public and private sector investment, all support programs are financed by the EU Structural funds rather than the public funds.

The allocation of financial resources in Latvia is more 'service-based'. It is impossible to achieve sustainable development or at least economic stability by reducing manufacturing, continuing to import consumption goods from abroad and expanding financial sector to pay for it. The Investment and Development Agency of Latvia in co-operation with the Ministry of Economics, who is responsible for development of innovation policy, should make a review of priority sectors of EU funding and to give preference to the development of new or improved products and processes.

One more important factor for well-functioning of Latvian IS is informational support, including statistical data. That is why authors decided to include in the Latvian innovation system the CSB.

One of the largest barriers hampering innovations in Latvia is that entrepreneurs often lack the understanding of the role of innovations in promoting competitiveness and growth. The Ministry of Economics should be actively involved in popularisation of examples of innovation good practices and implementation of measures of public awareness of innovation proves. One more significant aspect is that CSB in co-operation with the Investment and Development Agency of Latvia, the Ministry of Economics, enterprises and other ministries should achieve an agreement on the definition of innovations used in Latvia.

Legislation and development of concept of the Latvian innovation system is needed.

\section{References}

Bolı̌škovs, S. (2008). Inovatīvā darbība Latvijā. Rīga: Jumava.

Country Profile - Latvia. European Parliament. Retrieved: http://www.europarl.europa.eu/ [24 February 2013].

Europe 2020 targets: research and development. Eurostat. Retrieved: http://ec.europa.eu/europe2020/pdf/themes/12_ research_development.pdf [25 February 2013].

Innovation and Enterepreneurship. Enterprise Europe Network Latvia. Retrieved: http://www.een.lv/pakalpojumi/ inovacija-un-uznemejdarbiba/termini-un-skaidrojumi [25 February 2013].

Innovation Union Scoreboard 2011. European Commission. Retrieved: http://ec.europa.eu/enterprise/policies/ innovation/files/ius-2011_en.pdf [25 February 2013].

Jesiļevska, S. (2012). Methodological aspects of innovation statistics and innovativeness of Latvia. Lithuanian Journal of Statistics, Vol. 51(1), p. 57-65.

Jesilevska, S. (2012a). Statistical aspects of collecting innovation data. Journal of Economics and Management Research, Vol. 1, p. 54-66.

Jesil̨evska, S. (2012b). Innovation in a knowledge-based economy and Latvia's innovative performance. Humanities and Social Sciences. Latvia, Vol. 20, Issue 2, p. 67-85.

Johnson, B. (1992). Institutional learning. In: B. A. Lundwvall (ed.). National Systems of Innovations. London: Pinter.

Lundvall, B. A. (ed.) (1992). National Systems of Innovation: Towards a Theory of Innovation and Interactive Learning. London: Pinter.

Lundvall, B. A. et al. (2009). Introduction. Handbook of Innovation Systems and Developing Countries. Ed. J. Lundvall, V. Chaminade. Cheltenham. Northampton: Edward Elgar, p. 1-30.

Niosi, J. (2002). National systems of innovations are "x-efficient" (and x-effective). Why some are slow learners? Research Policy, Vol. 31, p. 291-302. 
Othman, A. (2005). The Role of Statistics in Factual-Based Policy-Making. Retrieved: http://www.statistics.gov.my/ portal/download_journals/files/2005/Volume1/Contents_Article_Aziz.pdf [8 February 2013].

Programming Period 2007-2013. EU Funds. Retrieved: http://www.esfondi.lv/page.php?id=658 [23 February 2013].

Program for Promotion of Business Competitiveness and Innovation 2007-2013. (2007). Ministry of Economics of Republic of Latvia. Retrieved: http://www.em.gov.lv/images/modules/items/KVIP_eng\%20(2).pdf [27 February 2013].

Research and Development and Innovation Statistics. (2012). Statistical Data Collection. Riga: Central Statistical Bureau of Latvia.

Statistics Explained. Eurostat. Retrieved: http://epp.eurostat.ec.europa.eu/statistics_explained/index. php?title=File:Enterprise_size_class_analysis_of_non-financial_business_economy_by_country,_2009.PNG\&filet imestamp=20120410135400 [23 February 2013].

Watkins, A., Agapitova, N. (2002). Creating a 21st Century National Innovation System for a $21^{\text {st }}$ Century Latvian Economy. World Bank.

World Bank. (2000). Report on Development Indicators (WDI). Washington, D.C.: World Bank.

\section{LATVIJOS INOVACINE VEIKLA IR INOVACIJUQ SISTEMA}

Daina Šķiltere, Svetlana JesiL̨evska

Latvijos universitetas (Latvija)

\section{Santrauka}

Nacionalinės inovacijų sistemos tyrimai ir jos silpnujų bei stipriujų pusių analizė yra labai svarbūs, siekiant formuoti efektyvią paramos inovacinei veiklai politiką. Paramos inovacinei veiklai politika turi ¿̇vertinti nacionalinės inovacijų sistemos savitumą, neapsiriboti tik universaliais sprendimais. Iki šiol Latvijos inovacijų sistema mažai tyrinèta. Šio straipsnio tikslas - aptarti Latvijos inovacinę veiklą ir pateikti siūlymų, kaip tobulinti inovacinę Latvijos sistemą. Šis tyrimas leidžia nustatyti nesutapimus tarp esamų problemų ir vykdomos politikos, išryškina paramos inovacinei veiklai politikus trūkumus.

PAGRINDINIAI ŽODŽIAI: inovacine veikla, inovacine sistema, statistinè informacija.

JEL KLASIFIKACIJA: C10, O31. 